\title{
Marketing and Artists
}

\author{
Pj. Forrest ${ }^{1, *}$, William S. Piper ${ }^{2}$ \\ ${ }^{1}$ Graduate School of Business, Alcorn State University, Natchez 39120 Mississippi, United States \\ ${ }^{2}$ Sun City Center, 33573-7359 Florida, United States
}

Copyright $(2018$ by authors, all rights reserved. Authors agree that this article remains permanently open access under the terms of the Creative Commons Attribution License 4.0 International License

\begin{abstract}
This paper explores the relationship between Marketing and Artists and proposes that it is a relationship that is beneficial to both parties. Once there was a perception that art must be non-commercial to be considered art. This does not take into account that art must be recognized and accepted by society to attain the value and recognition [1] the artist desires. We postulate that this acceptance can be gained by exposure through marketing as well as traditional artistic avenues. Examples are given of how some of the most famous art today became famous not because of the artistry, but because of an external force unrelated to the art. We examine 4 artists - Warhol, Lautrec, Rockwell and Steinlen - who are as famous, or even more famous, due to their commercial art. Examples are given of how some of the most famous art today became famous not because of the artistry but because of an external force unrelated to the art. We examine 4 artists - Warhol, Lautrec, Rockwell and Steinlen - who are as famous, or even more famous, due to their commercial art. Would Lautrec or Steinlen ever have been heard of if not for their iconic poster ads of the late 1800's? And while Warhol and Rockwell didn't become famous for advertising exactly, Warhol gained fame by painting a can of soup, and Rockwell was best known for his Saturday Evening Post covers. Art and marketing are natural allies.
\end{abstract}

Keywords Marketing, Advertising, Art, Commercial Art

\section{Introduction}

The perception that art must be non-commercial to be considered art misses the point that art must be recognized and accepted by the majorities of audiences to reach a goal of eminence and admiration that creates value and recognition [1]. We postulate that the artists will gain as much esteem from a commercial or marketing connection as the marketer will from the art connection and the artist will be more readily recognized. The primary result desired by commercial advertisers is broad coverage as this provides an expanded audience for their offering and the artists' recognition. For the artists a single impression by a single viewership via the masses creates awareness possibly leading to popularity well beyond a yearlong gallery show [2]. Cutting [3] showed in the power of exposure that repetition not only sets a partiality for art in the mind of the viewer, but it overcomes the effect of known fondness for fine art. Beauty may be in the eye of the beholder but if a person is exposed to an artistic accomplishment and assured of its artistic or cultural value anything may become beautiful or more appropriately well-known.

For some years a debate raged, primarily in the artistic community, regarding whether art which was created for commercial purposes was indeed "Art." [1] According to the "pure artists" an artist who did commercial work had "sold out." Receiving recompense for the work meant the artist was not suffering for his art. Fortunately for both Art and Advertising such artists as Toulouse Lautrec, Norman Rockwell, Andy Warhol and Theophile Steinlen embraced the form and found not only a means of artistic expression, but a way of increasing their popularity and raising their profile.

From a marketing perspective - we just don't care. Whether advertising art is created by a master with his or her brushes or by a graphic artist with a computer, advertisements have to fulfill their role in the Promotional mix - grab the target markets attention and assist in achieving the communications objectives of the ad. However, history informs us that great art by a great artist has an immense potential to fill that role. Artists too benefit from this association; some artists are more famous for their commercial art than their traditional pieces. The relationship between Art and Advertising is strong and often mutually beneficial. In this paper we give some examples of the existence of this bond and examine the work of four famous artists Warhol, Lautrec, Rockwell, and Steinlen - for their contribution to the Art of Advertising. This is not intended to be a comprehensive research paper, but rather an informative one which describes the relationship between marketing and the selected artists. These mutually beneficial relationships are 
expected to continue, as marketing continues to seek out artists.

\section{Methodology}

As this is not a scientific paper, the authors subjectively selected four artists, Warhol, Rockwell, Lautrec and Steinlen, who had a strong relationship to advertising. Lautrec was chosen as he gained fame as an artist via his commercial work. Warhol was a choice as, prior to becoming the pop cultural icon he is today, and he earned his living as a commercial artist. Rockwell was included as he is one of the few artists who continued to do commercial art after his artistry was noted and acclaimed. And lastly Steinlen was included because although his name is not known, his iconic La Chat Noir cat is a well-recognized cultural image.

\section{Examples}

The power of exposure for art was exemplified over 100 years ago by Gustave Caillebotte's 1897 gift of art to the French government. Upon his death Gustave Caillebotte made a bequest to the State of France of his entire Impressionists collection of art [4]. This example provides just one of many instances of creating notoriety and fame from a single act that draws attention. All the original 8 artists, Camille Pissarro, Edgar Degas, Paul Cézanne, Alfred Sisley, Claude Monet, and Pierre-Auguste Renoir, Jean Millet and Édouard Manet, works that had been identified by the bequest had been rejected by art critics and the French government as being unworthy of exhibition in the National Gallery [5]. A battle raged in the news media for several years before a set of paintings by the obscure impressionists' painters belong in a museum [4]. The paintings were endorsed by the press and eventually all of the obscure paintings became well accepted and recognized as masterpieces primarily because the celebrity and notoriety developed because of the extraordinary gift.

The Mona Lisa, by Leonardo da Vinci, is arguably the most famous painting in the world but was once regarded as a relatively mid-level painting hanging in the Louvre [6]. In 1894 the "Mona Lisa" was valued at 90,000 francs compared to Raphael's "the Holy Family" valued at 600,000 francs or the 150,000 francs estimated value of the "Supper at Emmaus" by Titian [Tiziano Vecellio]. This is where the real story begins. The Mona Lisa gained international fame in 1911 when it was stolen by Vincenzo Peruggia, an unemployed painter from Italy [7]. The French press declared the painting had historical significance and replicas of the Mona Lisa were published in the newspaper monthly for almost two years [8]. The general population gained knowledge of not only the theft but also knowledge of a painting that was unfamiliar to then previously. This new and expanded knowledge of an artistic piece of work brought the attention on many more people to the theft. Once the art was repatriated the populous could not get enough of the painting. Increased attention to the painting brought it fame. For the first time in history people lined up outside the Louvre to see the vacant spot on the wall where the Mona Lisa once hung during the absence period [8]. The fuss over this painting became an obsession with the French people and the Mona Lisa became the worlds most treasured painting [9]. The painting was not recovered for several years, and the press continued to push the authorities to find and return the now world-famous art work [6]. The return of the painting and capture of Vincenzo Peruggia in 1913, which by its sheer duration of publicity, created an art icon of the Mona Lisa painting. This necessitated a reevaluation by the artistic society of the relative standing for the painting in the art community; the 1962 insurance value of the Mona Lisa was $\$ 100$ million dollars [10].

\section{The Artists}

\subsection{Andy Warhol}

A more contemporary example of the impact attention and notoriety on art is the revealed by the creativity of Andy Warhol, pop artist of the 60's generation who gained fame by painting a soup can (Figure 1.). At the time he was working as a commercial artist for companies such as Miller Beer and Halston (Figures 2 and 3. Andy's first gallery exhibit features 32 hand-painted cans of soup that resembled the original lithographs of the Campbell's Soup Company labels (Figure 1.) The paintings created a mild sensation in Los Angeles and much success with the youthful art and film community in California. This notoriety became the catapulted Andy Warhol to the status of a Pop art Icon. Warhol noted years later that this was his finest and most rewarding work [11]. The recognition he gained from this one artistic rendering really derived from the relationship people found to the famous product line. The designs were replicated in many magazines and newspapers giving the artists the recognition that makes artists famous. Eventually the Campbell Soup Company recognized the value of the painting to their product line and adopted the color scheme and Warhol design. The recognition by the public and the familiarity of the subject combined to make the painting a success. Here art leads marketing to accept a work that befits the products sales. Artists and Marketers benefit from mutual cooperation.

Although catapulted to fame for his iconic Campbell's Soup can portrait (Figure 1,) Andy Warhol was an avid advertising proponent who designed dozens of ads for many diverse companies such as Vanity Fair, Glamour, Schiaparelli and Bergdorf Goodman. Coke, Miller and Perrier. Contrary to the standing controversy -Warhol 
believed that commercial art was a legitimate art form stating "Business Art is a much better thing to be making than Art." He also incorporated a good deal of humor into his art (Figure 4.)

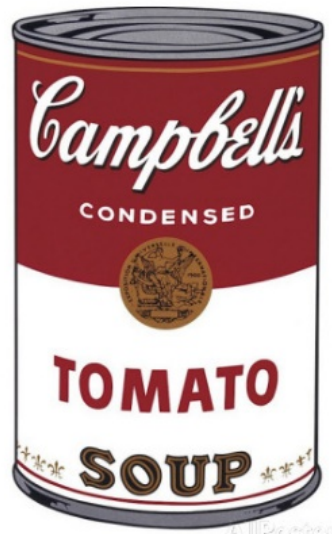

Figure 1. Warhol Soup Can

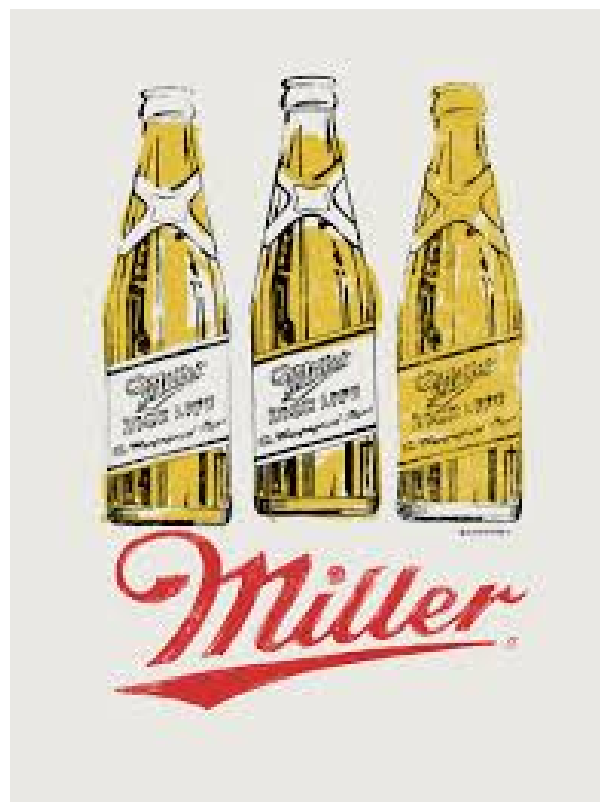

Figure 2. Warhol Miller Ad

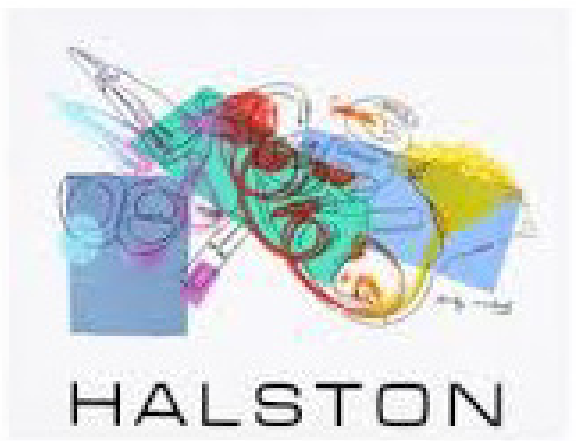

Figure 3. Warhol Halston Ad

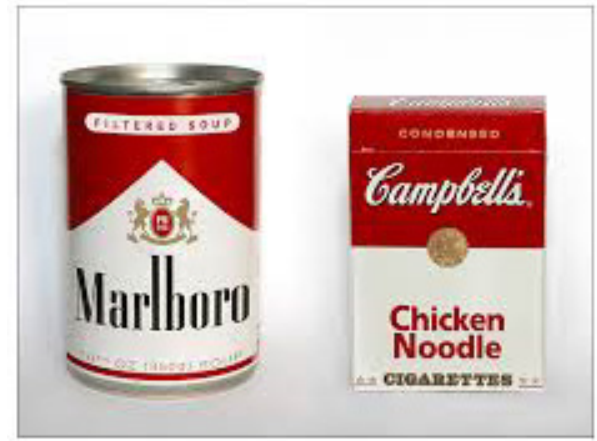

Figure 4. Warhol Juxtaposition

\subsection{Henri Toulouse Lautrec}

Henri Toulouse Lautrec is probably the artist most famous for his commercial poster art. Lautrec was a Parisian artist in the Montmartre district during the 1880's and 1890's. He was known for his intense colors, strong lines and simple forms. Lautrec immersed himself in the Paris nightlife. Although from a wealthy background, chose to live among, and paint, the poor who were the citizens and entertainers who populated the streets, bars and cabarets. His various paintings, posters and sketches have provided a vivid and intimate glimpse of life on the streets of Paris. [12]

The majority of his works depict the life of the working poor of Paris. While his paintings are well known and highly valued, the most famous of his works are the posters and advertisements he did for Montmartre business establishments. Perhaps the most famous of these is the Moulin Rouge poster featuring Jane Avril (Figure 5.) The success of his commercial art made it possible for Lautrec's ability as an artist to be recognized and he is now known for his exceptional artistic ability.

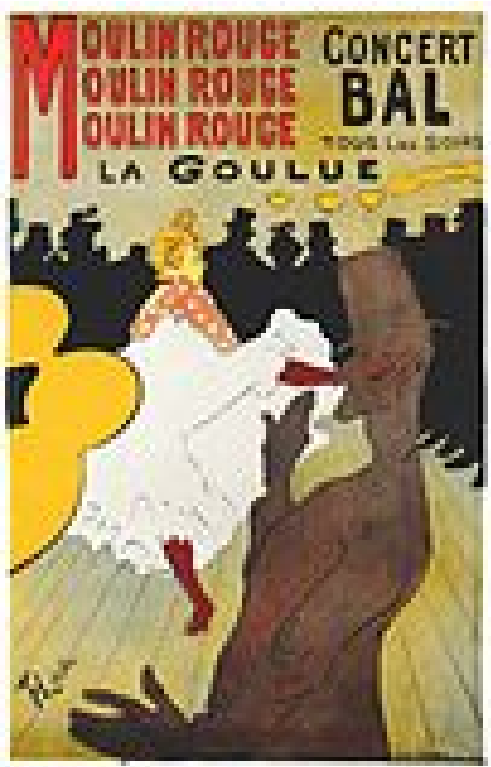

Figure 5. Lautrec Moulin Rouge Poster 
However, he created many other visual masterpieces for advertising purposes, such as the four shown next (Figures 6-9.)

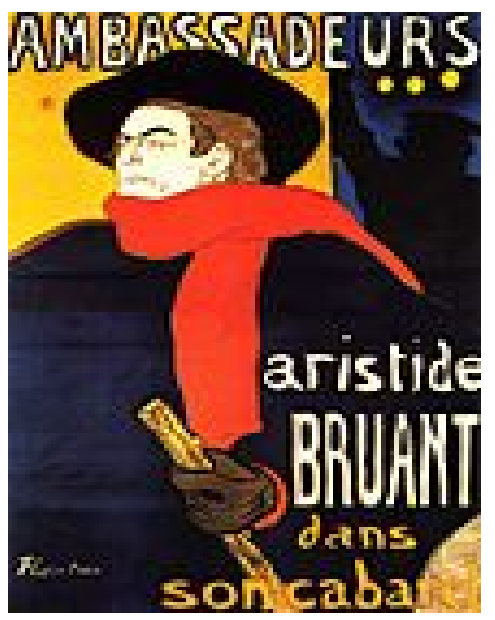

Figure 6. Lautrec Ad 1

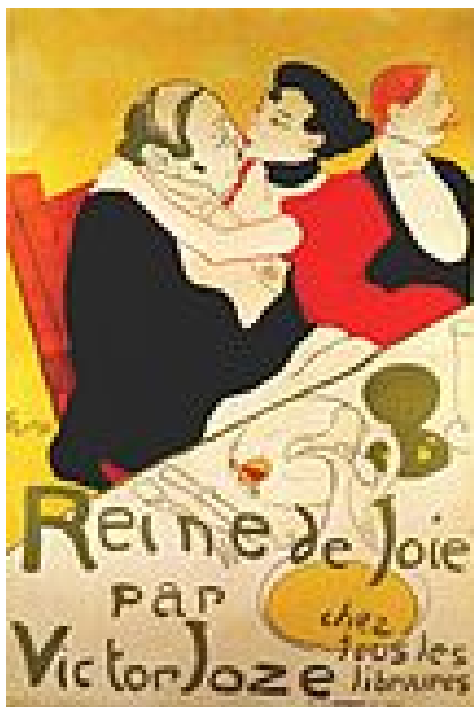

Figure 7. Lautrec \#2

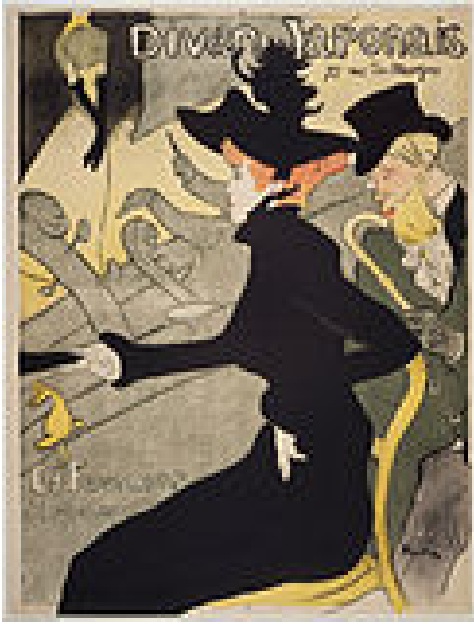

Figure 8. Lautrec \#3

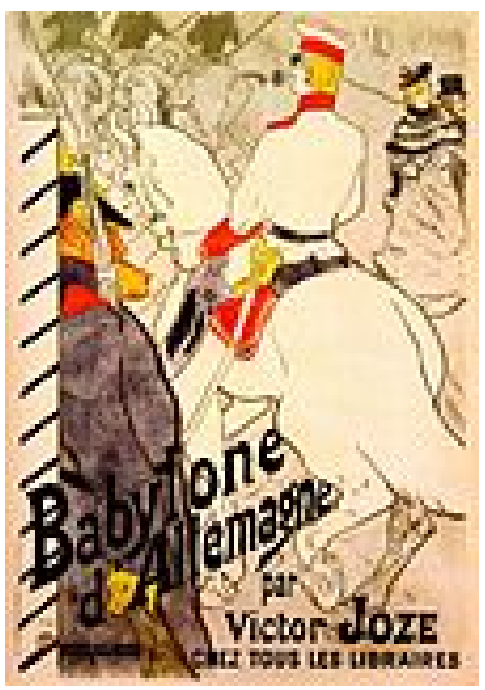

Figure 9. Lautrec \#5

\subsection{Norman Rockwell}

Norman Rockwell is an artist primarily known for his stunning and iconic cover art for the Saturday Evening Post. Less well known is that Rockwell was an inveterate advertising artists and created hundreds of ads during the time period of 1914-1976. His commercial work included companies such as Heinz, Del Monte, Borden's, United States Marine Core, Kellogg's, Coke, Pepsi, Fortune, The New Yorker, Cosmopolitan, Jell-O, Orange Crush and literally dozens of others (Figures 10-12.)[13]

Even in a very commercial vein the images Rockwell creates celebrate his unique artistry. His Utopian Vision of American society sculpted an altered conduit to the fashionable Abstract Expressionism of the era. Rockwell is now acknowledged as one of 20th Century America's most enduring artists, spanning both 'high' and 'low' art. [14]

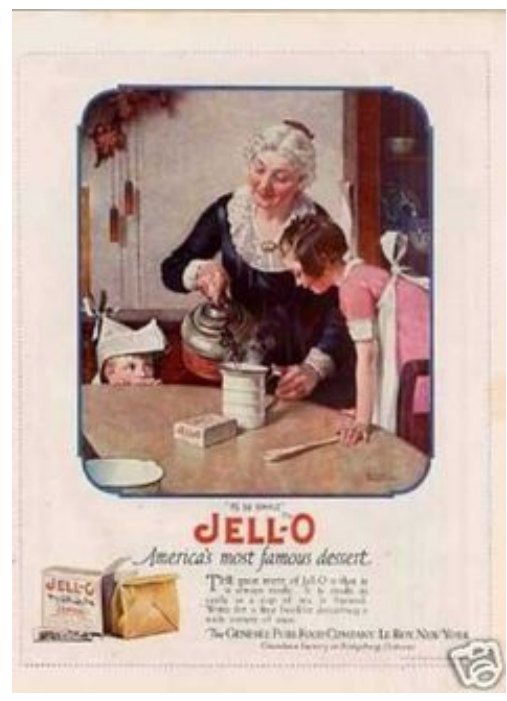

Figure 10. Rockwell \#1 


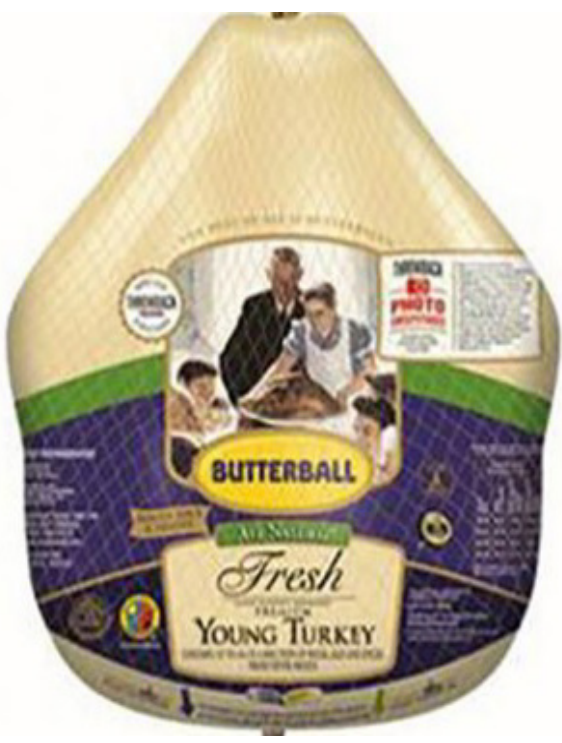

Figure 11. Rockwell \#2

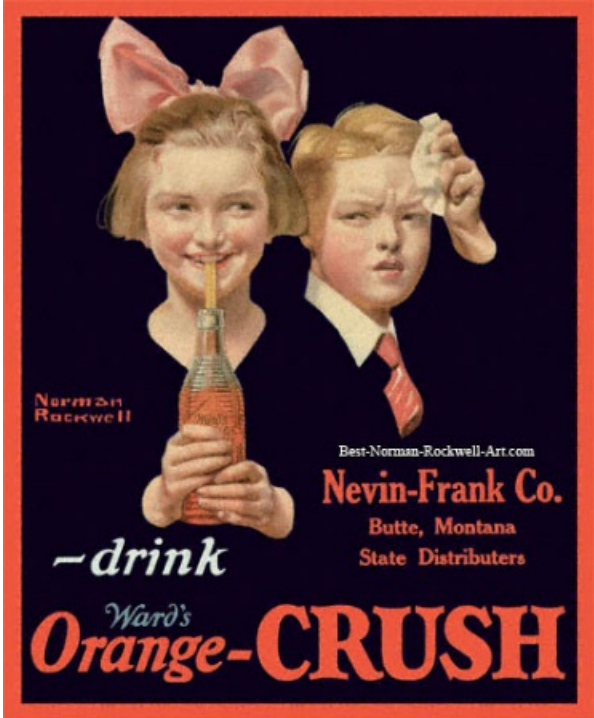

Figure 12. Rockwell \#3

\subsection{Theophile Alexander Steinlen}

In the case of Steinlen, you may not recognize the artist, but his iconic cat is a familiar symbol in our culture (Figure 13.) Also working in the Montmartre district of Paris in the early 1890's Steinlen fell in with the crowd of artists that patronized Le Chat Noir, a café and club. This led to his commission to do the poster for the club, which led to further commercial jobs (Figures 14-16) and eventually purely artistic endeavors.

He became a well-known artist of the time, producing many prestigious works. Today his works reside in many museums around the world including at the Hermitage Museum in St. Petersburg, Russia. and the National Gallery of Art in Washington, D.C., United States. Without his iconic Chat Noir poster and other commercial art, he would probably not have become known.

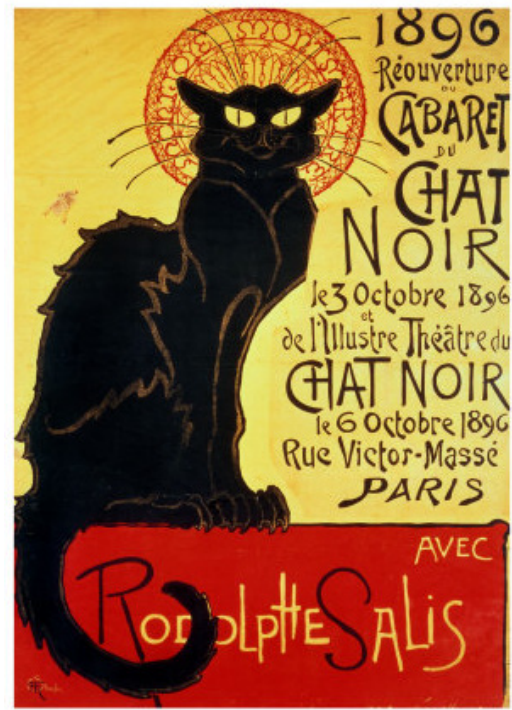

Figure 13. Steinlen Iconic Cat Poster

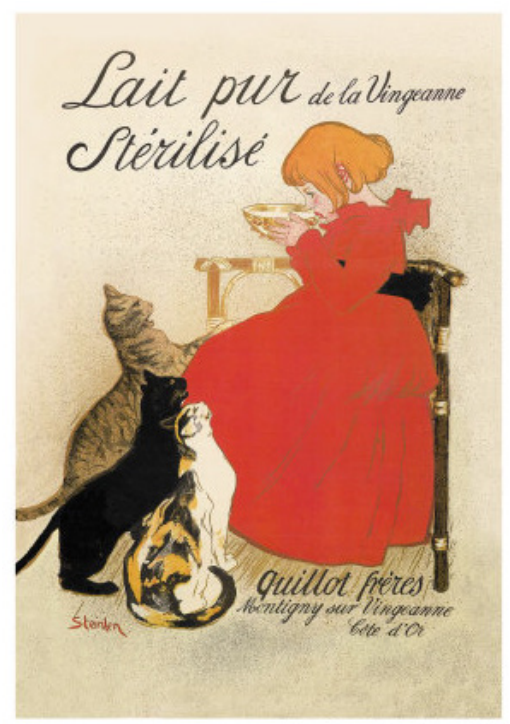

Figure 14. Steinlen \#1

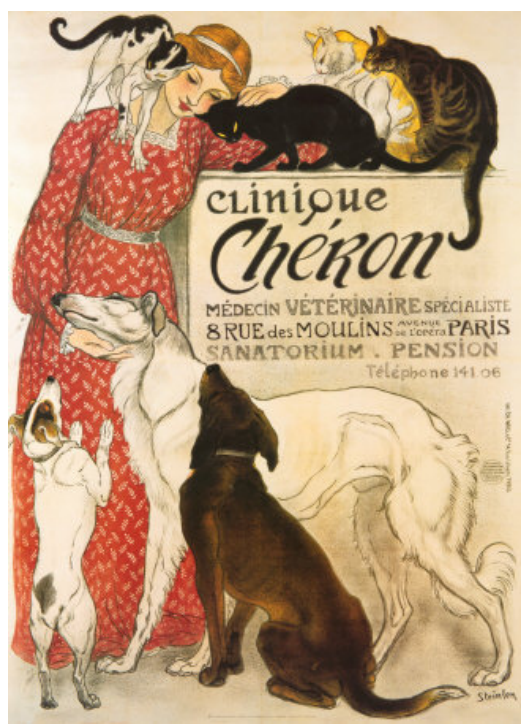

Figure 15. Steinlen \#2 


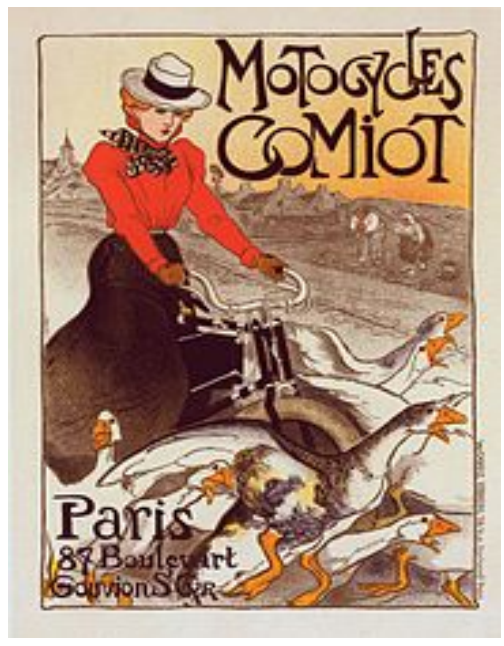

Figure 16. Steinlen \#3

\section{Discussion}

Commercial and marketing/advertising utilization of art are not contaminants but rather the advocates of the art community by promoting and exposing art to a broader community. This is a symbiotic relationship with a complex mix of opportunity and strength combining to enhance the assessment of art by the populist and providing a product recognition not before recognized. Both marketing and artists benefit from art that portrays a product in a favorable light or adds a level of distinction not before recognized.

Conversely, art benefits from advertising and product marketing by gaining a level of notoriety, recognition or fame which leads to mass acceptance and apperception. Many artists and their masterpieces strive for years to become accepted. Some never make the grade and others only reach a low level of recognition and appreciation. The traditional route to becoming known as an artist is problematical. Arts' connection to marketing and commercial cooperation places the art in front of as many people as is economically feasible using either mass, print or electronic media. In a minute or less, a piece of fine art that is part of an advertisement will be viewed by more people than most paintings would experience in a year at the Louvre.

Art and advertising are most often entirely separate, and many traditional artists look down upon commercial art. However marketing/advertising does two things for the artist: it exposes their art to a mass market and it pays them for it. Good commercial artists need not "struggle" nor navigate the treacherous waters of the artists "acceptable" route to fame. Marketing benefits from the attention these beautiful works of art by a great, but unknown, artist generates. Commercial art may not be the right fit for every product and artists, but neither does it prevent the genius of the artists from developing.

\section{Conclusions}

While some artists may consider themselves above the lowly commercial use of art, the artists described above are proof that beautiful, striking images can be created regardless of the intended medium. Each of them have created lasting images which have ensured their place in art and marketing history, and these are only four of the many artists who saw, and even embraced, advertising as an outlet for their astonishing works. Andy Warhol even took it a step farther and turned his advertising illustrations into museum quality art. Advertising has benefited from the art's ability to draw attention to and communicate the advertising message, and artists have benefited by increased exposure and publicity.

\section{REFERENCES}

[1] Waite Jr., Dwayne W. 2013 Beyond Madison Avenue, http://www.talentzoo.com/beyondmadison-ave/blog_news.php?articleID-12357.

[2] Sharrock, Lee 2011 "Art and Advertising; A Mutually Rewarding Relationship or a Marriage of Convenience?" More about Advertising. http://www.moreaboutadvertising .com/2011/01/art-advertising/

[3] Cutting, James. Impressionism and its Cannons, University press of America, Landham, MD. 2016

[4] Ringwald, John. The History of Impressionism, The museum of Modern Art, New York, New, York. 1961

[5] National Gallery of Art, 2015 www.nga.gov/content/ngawe b/exhibitions/2015/gustave-caillebotte.html.

[6] Sassoon, Donald, 2001 "Becoming Mons Lisa: The making of a Global Icon”, Harcourt, Inc. Orlando, FL.

[7] Watts, Duncan, 2011 Everything is Obvious: Once You Know the Answer, Crown Business, New York, New York.

[8] McKenzie, Sheena, $2013 \mathrm{CNN}$ report, "Mona Lisa: The theft that created a legend", http://www.cnn.com/2013/11/18/wo rld/europe/mona-lisa-the-theft/index.html.

[9] Thompson, Derek. Hit Makers: The Science of Popularity in an Age of Distraction, Penguin Books, Penguin Random House, New York. 2017

[10] The Guinness Book of World Records, 2016 "Mona Lisa Insurance value" http://www.guinnessworldrecords.com/se arch?term $=$ Mona + Lisa $+2016+$ insurance + value $\&=$.

[11] Ketner, Joeseph. Andy Warhol: Phaidon Focus, Phaidon, London, New York. 2013

[12] Pudles, Lynne. 2013 Scholastic.http://www.scholastic.com/ browse/article.jsp?id=3754694\&print $=1$

[13] Anonymous June $11^{\text {th }}, 2015$. Best Noman Rockwell Art. http://www.best-norman-rockwell-art.com/index.html

[14] Sharrock, Lee 2011. "Art and Advertising: a Mutually Rewarding Relationship or a Marriage of Convenience?" More about Advertising.https://www.moreaboutadvertising .com/2011/01/art-advertising/ 